\title{
ESP---A Way out of College English Living Crisis
}

\author{
Haiyan Kong \\ Shandong University of Technology, Jinan, China
}

Keywords: College English Living Crisis, ESP, Professional Development

Abstract: The credits of College English (CE) were decreased to fewer than 12 in many colleges. If a freshman meets the requirements of curriculum, he or she needn't take any CE courses. According to Cai Jigang, a leading scholar in English education and famous professor in Fudan University, CE will disappear from colleges and universities. Thereby, some CE teachers will confront with changing post or layoff. A way to solve this problem is to transfer from CE teachers to ESP teachers. so this paper provides some ways to change.

\section{Introduction}

ESP (English for Special Purpose) is becoming very hot in China. Colleges and Universities provide various ESP courses. In one hand, the lack of ESP teachers is a headache; but in the other hand, CE (College English) teachers, who teach non-English major students EGP (English for General Purpose), are confronting the problem of no courses to teach. Can CE teachers transfer to ESP teachers? And how to transfer? Those are the questions that will be studied in this paper.

\section{Severer situation which $\mathrm{CE}$ and $\mathrm{CE}$ teachers are confronting}

Credits of College English (CE) are shrinking in many colleges and universities. According to College English Teaching Program of 2007, credits of CE can be kept around 16. But actually, they are decreased to under 12 in many universities. If a freshman meets the requirements of curriculum, or passes CET4(College English Test band 4), he or she even needn't take any CE courses. As a College English teacher, I sensed this changing deeply. The total number of students doesn't change a lot, but our working-load was decreased significantly. "college English teachers will be teachers without courses to teach". According to Cai Jigang(2013), who is a leading scholar of ESP in Fudan University , "CE has no reason to exist in high institutions ,especially in some top universities; it will disappear" (Cai Jigang2013). Thereby, CE teacher will confront with changing post or layoff. Where CE will lead to? Will CE really disappear from college curriculum? If CE disappeared, the direct victim is CE teachers. Then, what's the way out for CE teachers? ESP is a good and proper way to deal with this severer situation,

ESP teaching will take the place of CE in the near future. Nowadays, children learn English from the early age. Their English is quite good when they entered into college. They have high efficiency in listening, speaking, reading and writing. Quiet a lot of students have no necessary to learn EGP 
(English for general purpose). Traditional vocabulary and grammar teaching failed to attract them. They lost their interests in EGP classes. As a result, skipping or absent from class is usual which imposes great pressure to CE teachers who are losing their senses of achievement. They are forced to change. Therefore, ESP was pushed forward. According to Liu Runqing (1999), "English learning in future will not be pure language learning any more. It must be involved into subject learning.” Specialized knowledge is required to teach ESP courses and the specialized knowledge is great challenge to many CE teachers since their majors mostly are literature, language teaching or linguistics. They are suffering great anxiety since they don't know what ESP exactly is. misunderstanding and prejudice to ESP scared CE teachers, which becomes the major barrier to the development of ESP in China. Can they adjust themselves to the new situation? Are they qualified for the new roles? To answer these questions, it needs to make clear that what ESP is?

\section{What is ESP}

ESP is the abbreviation to English for Specific Purpose. It came into being in the 1960s. It refers to the teaching of English for a clearly utilitarian purpose. This purpose is usually defined with reference to some occupational requirement or vocational training programs. Traditionally, ESP was regarded as a restricted language, English for Academic and Occupational Purposes, English with specific topics. In recent years, ideas on ESP are changing. According to 'Tree of ELT' (Hutchinson \& Waters, 1987, 17), ESP is the base of EST (English for Science and Technology), EBE (English for Business and Economics), and ESS (English for Social Studies). ESP is more general. It's not English for some discipline and not focuses on "what various specialisms have in common" (Hutchinson \& Waters, 1987, 19). They are all primarily concentrated on communication and learning skills. ESP should not be seen as "any particular language products" but an approach to language teaching which is directed by specific and apparent reasons for learning. ESP is not necessarily to focus on some subjects or a certain group of people. It's a teaching method (Anthony, 2011). It's revolution in linguistics. (Hutchinson and Waters 2002, 16).

According to Cai Jigang (2013) , “ESP has great difference with subject-based English. It isn't ESP but a bilingual teaching. Such courses should be taught by specialized teacher instead of CE teachers.” we should do real ESP teaching which all CE teachers are qualified for. Maybe it focuses on some area such as on law or business, but they highlight the communication skills and strategies instead of contents teaching. Thereby, EC teachers can be relaxed and relief. Only if they receive some training, can they do the job well.

\section{From CE to ESP---CE teachers’ professional development}

CE teachers should realize the challenging situation and manage to shift. ESP, as language used in special context and special field, has been a unique course. It's not simple piles of language skills and major knowledge. CE teachers should achieve the transition from EGP to ESP. It's not only changing the teaching contents, but also the mindset. To fulfill this changing, it needs the support of educational institutions, colleges and universities as well as the efforts of the individual teachers. The following are some ways for CE teachers shift to ESP teachers.

Sound ESP training system should be built. ESP has long history in some western countries, especially in USA. It appeared firstly in 1960s, and concerned with many areas. There are overall and sound training systems and models. Consulting their experiences, we can build our own training system. Colleges and universities should encourage CE teachers to have ESP training. Encouraging them to get training in summer and winter vocation. Provide them more chances and 
opportunities to observe or study in other colleges and universities. And give them support both in time and in finance.

ESP teachers should enhance the perception of professional development. They should be aware of the ESP developing trend and get clearly how to adjust themselves to the change of society. In order to improve, they should be sensitive to various news and opportunities which can perfect their self-development. Taking relative classes, reading professional Journals are also good ways to gain ESP skills. All in all, ESP teachers should know their needs and try their utmost to realize it.

Take workshop as a way of improving. Workshops are an excellent way to teach ESP teachers new skills or to help them learn new tasks. In order to be effective, a mature training workshop have carefully planned and developed to ensure that the subject matter is covered thoroughly and reinforced in a way that will allow trainees to use it on the job. In order to ensure everyone achieve the identified goals, they prescribe specific learning objectives and steps. After finishing the workshop, all the trainees are conducted evaluation. Feedbacks from the trainees on what they liked best and the areas that could be improved, would be incorporated into future training material or in development of other training workshops. In this way, proper workshops enable ESP teachers to gain the required capability and improve their professional development.

Another proficiency way for ESP teachers to improve is team-teaching. It's also known as co-teaching or collaborative teaching. Team teaching is an instructional strategy used across subject areas in a variety of methods. Teams are typically composed of between two and four teachers working collaboratively to plan thematic units and lesson plans in order to provide a more supportive environment for students. In ESP team-teaching, two models are often used. One is fulltime teaching, language teacher and Major teacher co-work together. They learn from each other and both benefit from it. Under such cases, both of them will soon be qualified ESP teachers. Another model is part-time collaborative teaching, in which language teacher and major teacher cooperative before or after class. Major teacher gives some guidance on teaching materials and contents; while language teacher deals with lexical and communications. This method is widely used in China.

ESP teachers should be encouraged to have field training in related field. It can help them to know more about the courses they are teaching. What's more, it can help teachers to accumulate teaching cases, which will enable the teaching more authentic and more close to the reality. Usually, classes that are closed to life are welcomed by students. So, teachers should be encouraged to observe or work in ESP related field as long as they have time.

Only if CE teachers sense the living crisis, can they get the power to change. When they get rid of the misunderstanding and prejudice to ESP, they can be confident enough to overcome their fear and be a highly proficient ESP teacher gradually.

\section{References}

[1] Tom Hutchinson \& Alan Waters English for Specific Purposes [M]. Shanghai Foreign Language Education Press, 2002, 11.

[2] Anthony, L, Three Steps to Developing a Successful Large-scale ESP Program in Asia [R]. 3rd International Conference on English for Specific Purposes in Asia, Oct22, 2011, Xi'an

[3] Cai Jigang. College English Teaching: Review, Reflection and Research [M]. Shanghai: Fudan University Press, 2006.

[4] Cai Jigang. Reflections on the Reorientation of College English Teaching in China [J]. Foreign Language Teaching and Research, 2010(4). 
[5] Cai Jigang. Research on College English Survival Crisis and Its Disciplinary Status [J]. China University Teaching 2013(2).

[6] Liu Runqing. The Development Trend of Foreign Language Teaching Research [J]. Foreign Language Teaching and Research, 1999(1.)

[7] Feng Yan. Going to Foreign Language: An Inevitable Choice for the Development of Public Foreign Language Teachers in Key Universities [J]. University Teaching Science, 2010(3).

[8] Qi Jing. Problems in the development of ESP teachers in transition period and research on coping strategies $[D]$. Chongqing University 